Univerzitet u Beogradu
Poljoprivredni fakultet
Institut za poljoprivrednu tehniku
Naučni časopis
POLJOPRIVREDNA TEHNIKA
Godina XLVI
Broj 4., 2021.
Strane: $49-57$

\title{
SYNTHESIS OF ACRYLATED EPOXIDIZED BIOBASED RESIN FROM GROUNDNUT SEED OIL
}

\author{
Kenechi Nwosu-Obieogu*1, Felix Aguele ${ }^{1}$, Linus Chiemenem ${ }^{1}$ \\ ${ }^{1}$ Department of Chemical Engineering, \\ Michael Okpara University of Agriculture, Umudike, Nigeria.
}

\begin{abstract}
In this study, groundnut seed oil was epoxidized in situ using hydrogen peroxide $(30 \%)$ and formic and acetic acid. The reaction conditions were monitored at a temperature of $70^{\circ} \mathrm{C}$, stirring speed of $750 \mathrm{rpm}$ and time of 6 hours. After epoxidation, a further modification was done using acrylic acid in the presence of hydroquinone at a temperature of $120^{\circ} \mathrm{C}$. Comparatively, peroxyformic acid performed more effectively than the peroxyacetic acid during epoxidation with an iodine value $(26.4 \mathrm{gl} / 100 \mathrm{~g}$ oil $)$ and oxirane content $(3.27 \%)$. FTIR analysis of the raw, epoxidized, and acrylated groundnut seed oil indicates that they were suitably functionalized.
\end{abstract}

Keywords: Groundnut seed oil, epoxidation, acrylation, formic acid, acetic acid.

\section{INTRODUCTION}

The use of petroleum-based feedstock in the manufacture of polymers has experienced some levels of decline in recent years due to the spiralling prices and high rate of depletion of the stocks. Furthermore, the unhealthy effect of polymer wastes on the environment resulting from its non-biodegradability is of great concern. This has inspired researchers to investigate sources of renewable natural materials as an alternative source of monomers for the polymer industry, which could substitute for the petroleum-based monomers for the manufacture of polymers, hence the need to develop biobased resins from plant seed oils [1-4].

\footnotetext{
*Corresponding Author. E-mail: kenenwosuobie@mouau.edu.ng
} 
Plant seed oils are essential raw materials in the formation of bio-based thermosets.

Different researchers have worked extensively on plant seed oil such as sunflower oil, soybean oil, groundnut seed oil and linseed oil due to their high iodine value and fatty acid profile (oleic, linoleic and linolenic acids) contained [5-7].

Vegetable oils containing unsaturated fatty acids triglycerides can be suitably epoxidized and further modified to biobased resins. These $\mathrm{C}=\mathrm{C}$ bonds are the reactive sites for the modifications [20]. Studies have revealed that rubber seed oil, soya bean oil, sesame seed oil, melon seed oil and groundnut seed oil containing high unsaturated fatty acid triglycerides can be modified through several chemical processes [8-12].

Wool and Sun [13]. reported on various synthetic pathways by which an epoxidized plant oil can be suitably functionalized using acrylic acid to give acrylated epoxidized triglycerides and maleic anhydride to give malenized triglycerides.

Groundnut is a principal oilseed crop that is cultivated on a large scale throughout the world. It is an annual crop principally for its edible oil and protein-rich kernel seeds, borne in pods that develop and mature below the soil surface [14]. In India, 80\% of the groundnut produce is crushed to extract oil and accounts for $36.10 \%$ of the total oil production. Groundnut seed contains $44-56 \%$ oil and $22-30 \%$ protein on a dry seed and is a rich source of mineral (Phosphorous, calcium, magnesium and potassium) and vitamins E, K and B group [15]. The fatty acid composition consist of Iodine value $(\mathrm{g} / 100 \mathrm{~g})=85$; oleic acid $(18: 1)=46.8 \%$, linoleic acid $(18: 2)=33.4$. This composition makes the oil amenable to various chemical modification; it can be successfully epoxidized and further modified [12].

The use of bio-based resins has helped reduce fossil fuel consumption, and they have been utilized in the production of various products, such as inks, paints, coatings, and plastics. Also, it has been used in the production of technical materials for housing (doors, window frames, hot tubs and composite decking), for aerospace (aero craft wings, tails, propellers, and interior), boats, bathtubs, pools, storage tanks and in the manufacture of vehicle parts [10, 16-18]. This paper, therefore, adds value to groundnut seed oil by synthesizing epoxides and acrylates from its oil, which could be used as a substitute to the non-renewable ones made from petrochemical sources that have adverse effects on the environment. Table 1., below represents the fatty acids (oleic, linoleic and linolenic acids) present in groundnut seed oil.

Table 1. Composition of unsaturated fatty acids present in melon seed oil and their molecular weights, [12].

\begin{tabular}{|l|l|}
\hline \multicolumn{2}{|c|}{ Groundnut seed oil } \\
\hline Fatty acids & Composition (wt\%) \\
\hline Oleic acid & 53.0 \\
\hline Linoleic acid & 32.0 \\
\hline Linolenic acid & - \\
\hline
\end{tabular}




\section{MATERIAL AND METHODS}

\section{Materials}

Magnetic heater with a stirrer, Three-necked round bottom flask, Thermometer, Condenser, Feed funnel, Stirring bulb, measuring cylinder, weighing balance, Separation funnel, Rotary evaporator. Groundnut seed oil was used as raw material, Formic acid (85 wt $\%$ ), Acetic acid (85 wt\%), Hydrogen peroxide (30 wt\%), Sodium Carbonate, Distilled water, Acrylic acid, Hydroquinone powder, Toluene, Sodium sulphate.

\section{Methods}

\section{Epoxidation procedure}

(35 g) of groundnut seed oil was measured and placed in the three-necked round bottom flask, $2.43 \mathrm{~g}$ of formic acid was added to the flask, and the mixture was stirred continuously for $30 \mathrm{~min}$. Then $16.15 \mathrm{~g}$ of $30 \%$ aqueous hydrogen peroxide was added drop-wise to the reaction mixture as an oxygen donor while stirring. The mole ratio of the components used was 1:1.5:0.5, $\mathrm{H}_{2} \mathrm{O}_{2}$ : $\mathrm{HCOOH}$. After the complete addition of hydrogen peroxide, the mixture was heated under reflux and maintained at a temperature of $70^{\circ} \mathrm{C}$ with rapid stirring. The rapid stirring was maintained throughout the experiment to achieve fine dispersion of oil and avoid high peroxide concentration zones that could lead to an explosive mixture. Samples were collected hourly from the set-up for analysis. The collected samples of epoxidized melon seed oil (EMSO) were then washed with a solution of $10 \mathrm{~g}$ of sodium carbonate mixed in $200 \mathrm{ml}$ of distilled water to remove the free fatty acids and other unwanted components. The $10 \mathrm{~g}$ of $\mathrm{Na}_{2} \mathrm{CO}_{3}$ was first dissolved in $100 \mathrm{ml}$ of distilled water before the remaining $100 \mathrm{ml}$ was finally added, mixed with the sample and separated using a separation funnel. Subsequent extraction was used to recover the remaining samples after washing.

\section{Synthesis of Acrylated epoxidized groundnut seed oil AMMSO)}

$35 \mathrm{~g}$ of epoxidized melon and groundnut seed oil was heated at room temperature, acrylic acid (4.89 g) containing hydroquinone ( $0.013 \mathrm{~g}$ of $0.25 \mathrm{wt} \%$ acrylic acid) was added after $30 \mathrm{~min}$. The reaction mixture was heated under reflux from 8 to 12 hours under constant stirring. The obtained product, Acrylated epoxidized groundnut seed oil, was then isolated.

\section{Characterization of groundnut seed oil}

The pure, epoxidized, and acrylated groundnut seed oil was characterized using Fourier Transform Infrared (FTIR) Spectroscopy Technique to determine surface functional groups present. The FTIR analyses were carried out on the samples using Shimadzu FT-IR-8400S Spectrophotometer with a resolution of $4 \mathrm{~cm}^{-1}$ in the range of $400-5000 \mathrm{~cm}$. 


\section{Analytical techniques \\ Iodine value}

Wiji's method of the Association of Oil Chemists determined the iodine value of the test oil sample. First, $0.5 \mathrm{~g}$ of the sample was poured into a conical flask. Next, $10 \mathrm{ml}$ of carbon tetrachloride was added to the oil and shook to allow the oil to dissolve. Also, 20 $\mathrm{ml}$ of Wiji's iodine solution was later added to the mixture, stirred vigorously, stoppered and kept in the dark for 30 minutes. Subsequently, $15 \mathrm{ml}$ of potassium iodide solution followed by $100 \mathrm{ml}$ of distilled water was added. The mixture was titrated against $0.01 \mathrm{~N}$ sodium thiosulphate solution. A reagent black was titrated as well.

The iodine value of epoxidized samples was calculated after analysis using the formula in eq. (1).

$$
I V=\frac{(B-S) \times M \times 12.69}{W}
$$

Where:

IV = Iodine value of samples

$\mathrm{S}=$ Volume of $\mathrm{Na}_{2} \mathrm{~S}_{2} \mathrm{O}_{3}$ used for sample $(\mathrm{ml})$,

$\mathrm{B}=$ Volume of $\mathrm{Na}_{2} \mathrm{~S}_{2} \mathrm{O}_{3}$ used for blank $(\mathrm{ml})$,

$\mathrm{W}=$ Weight of sample used $(\mathrm{g})$,

$\mathrm{M}=$ Molarity of the $\mathrm{Na}_{2} \mathrm{~S}_{2} \mathrm{O}_{3}$ used.

\section{Oxirane Oxygen content}

The percentage of the oxirane oxygen was determined by the direct method established by using a hydrobromic acid solution in glacial acetic acid. First, the content of oxirane oxygen (O.O.) was calculated according to the consumed amount of the halogen atom.

The Oxirane Oxygen Content of the analyzed samples was calculated using the formula in eq. (2).

$$
O V=\frac{(B-S) \times M \times A_{o} \times 100}{1000 \mathrm{~W}}
$$

Where:

$S=$ Volume of $\mathrm{NaOH}$ used for sample $(\mathrm{ml})$

$B=$ Volume of $\mathrm{NaOH}$ used for blank (ml)

$M=$ Molarity of the $\mathrm{NaOH}$ used

$W=$ Weight of sample used $(\mathrm{g})$

$A_{o}=$ Atomic weight of oxygen 


\section{RESULTS AND DISCUSSION}

Table 2. Iodine and oxirane values of the epoxidized samples

\begin{tabular}{|l|c|l|}
\hline \multicolumn{1}{|c|}{ Samples } & Iodine value (g/100 g of oil) & Oxirane value (\%) \\
\hline $\begin{array}{l}\text { Epoxidised groundnut seed } \\
\text { oil with acetic acid }\end{array}$ & 26.92 & 2.00 \\
\hline $\begin{array}{l}\text { Epoxidised groundnut seed } \\
\text { oil with formic acid }\end{array}$ & 26.4 & 3.27 \\
\hline
\end{tabular}

The iodine value and oxirane oxygen content are essential parameters in the characterization of epoxidized vegetable oils [19]. While the iodine value indicates the remaining unsaturated fatty acid triglyceride present after the epoxidation reaction, the oxirane oxygen content indicates the epoxy groups incorporated in the products. From the results presented in Tab. 2, it was observed that the epoxidized groundnut seed oil with formic acid had better-functionalized samples than the oil epoxidized with acetic acid. With formic acid, the iodine value was obtained as $26.4 \mathrm{~g} / 100 \mathrm{~g}$ oil, which is lower than $26.92 \mathrm{~g} / 100 \mathrm{~g}$ oil for acetic acid and the oxirane value of $3.27 \%$ was obtained for samples where formic acid was used. This is a higher than $2.00 \%$ value result obtained for samples where acetic acid was used. Although the oil samples were epoxidized successfully with both formic and acetic acids as used in this study, the results indicated that formic acid gave a better performance than acetic acid for the epoxidation process of groundnut seed oil. This result agrees with the findings of [19]

Figure 1. FT-IR analysis of a raw sample of groundnut oil

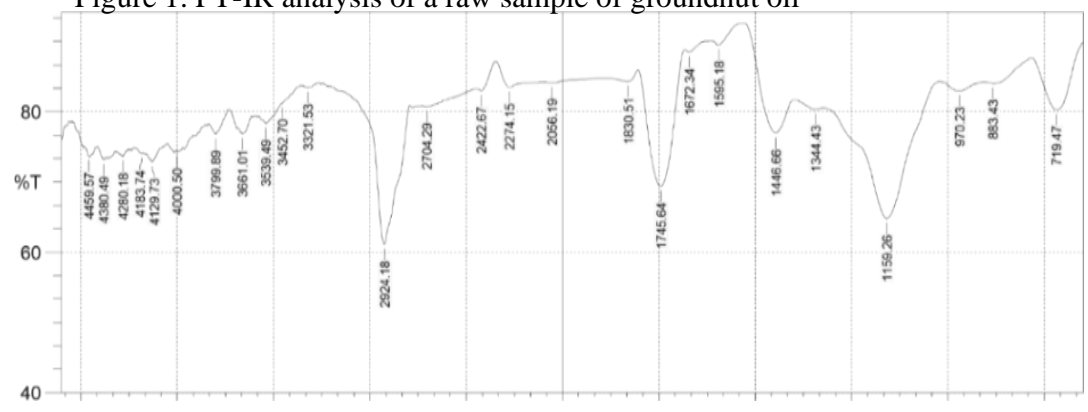

Figure 2. FT-IR analysis of epoxidized groundnut oil sample with acetic acid

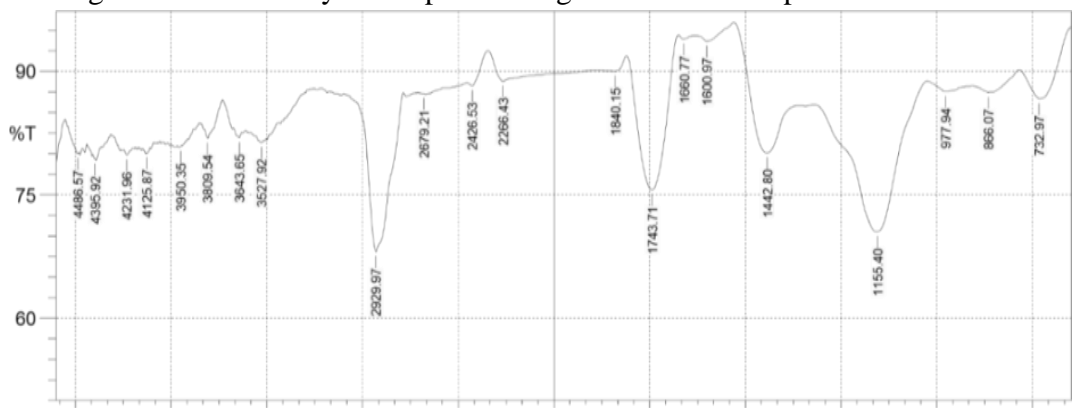

Figure 3. FT-IR analysis of epoxidized groundnut oil sample with formic acid

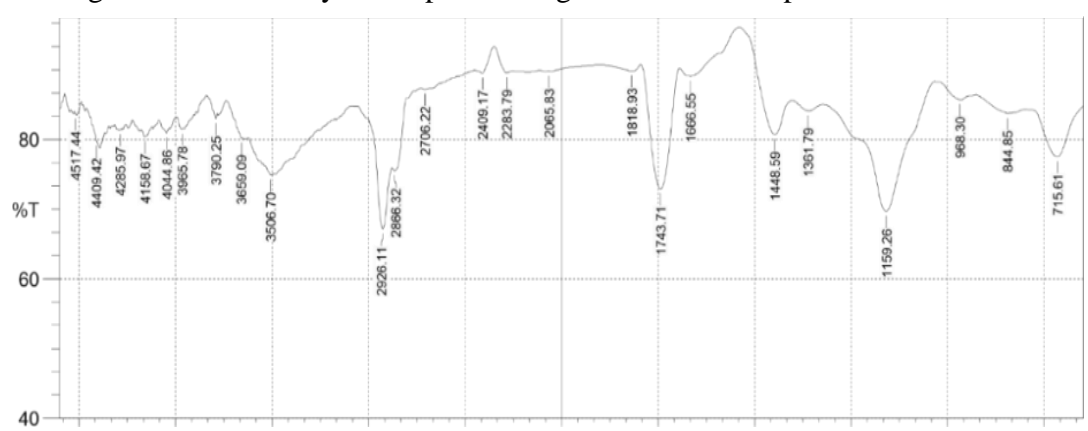


Figure 4. FT-IR analysis of acrylated epoxidized groundnut oil sample with acetic acid

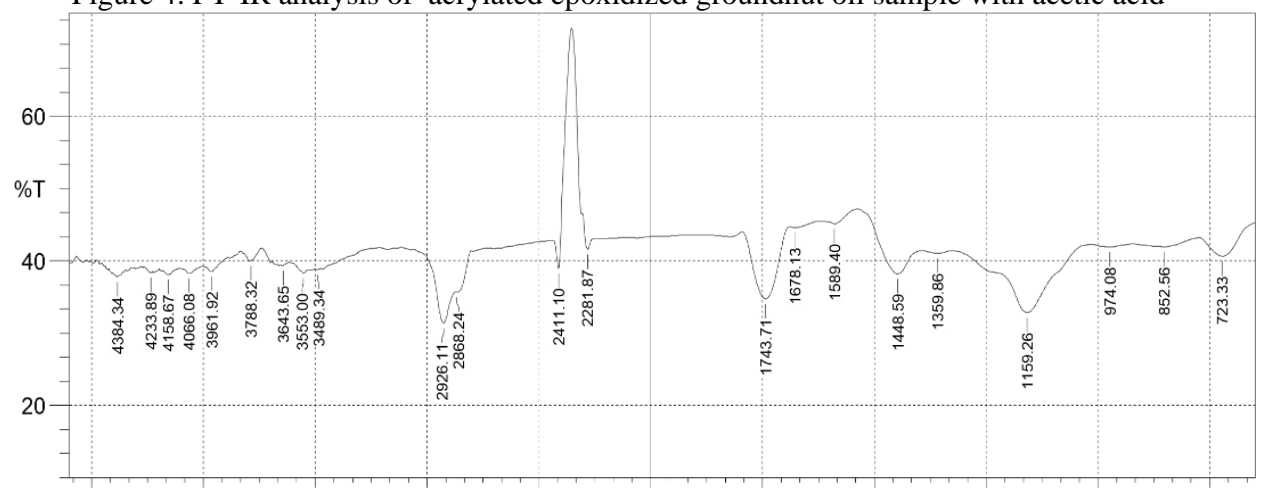

Figure 5: FT-IR analysis of acrylated epoxidized groundnut oil sample with formic acid

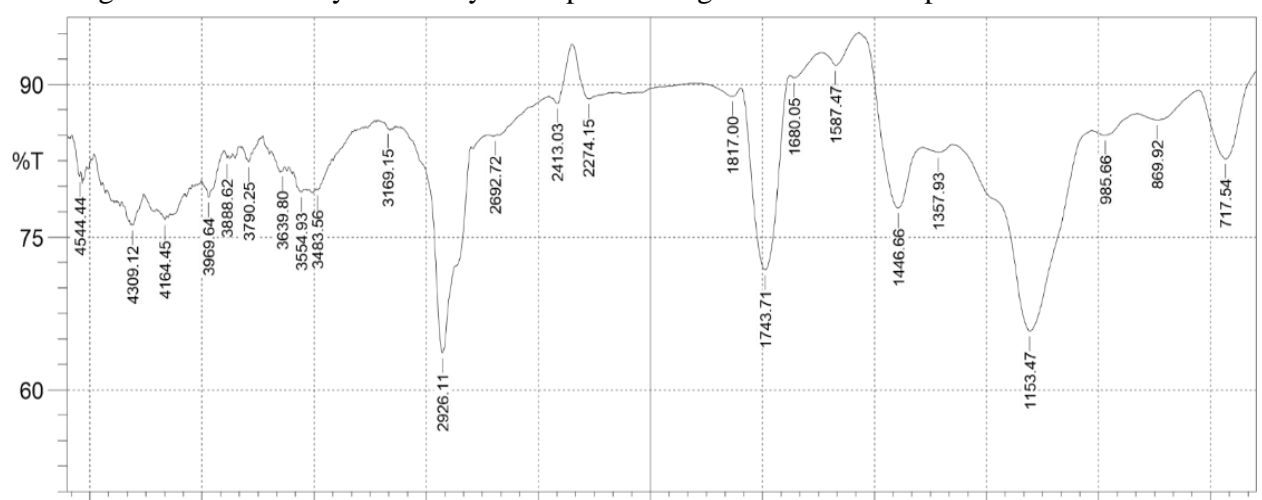

\section{Discussion}

From results of the FT-IR spectra as presented in Fig. 1-5, the presence of carboncarbon double bonds $(\mathrm{C}=\mathrm{C})$ were observed in the untreated groundnut seed oil, which was indicated by the appearance of peaks at $3500 \mathrm{~cm}^{-1}$ and $3000 \mathrm{~cm}^{-1}$ as shown in Fig. 1, this indicates the functionality of the oil. As presented in Fig. 2 in the acetic acid epoxidized groundnut seed oil, the absorption band for the epoxy group was indicated by the single peak at $3527.92 \mathrm{~cm}^{-1}$. For the same oil epoxidized with formic acid, the peak was also indicated at $3506.70 \mathrm{~cm}^{-1}$; this shows a close margin between both carboxylic acids, indicating their suitability in the epoxidation process. Fig. 3 shows that the oils were suitably epoxidized in both cases, and these results were achieved after six hours $(6 \mathrm{~h})$ reaction time, stirring speed of $750 \mathrm{rpm}$ and $70^{\circ} \mathrm{C}$ temperature. 
The I.R. spectra for the acrylic acid modified samples revealed acrylic group indicated by the peak at $3489 \mathrm{~cm}^{-1}$ for the acrylated epoxidized groundnut seed oil with acetic acid and $3483 \mathrm{~cm}^{-1}$ for the acrylated oil epoxidized with formic acid, as shown in Fig. 4 and Fig.5, respectively. These peaks were observed to be absent in both the epoxy resin and the pure, unmodified groundnut seed oil, which was an indication that the epoxy groups in the epoxidized oils have been converted to acrylated groups after the acrylation process was carried out on the epoxidized groundnut seed oil, this result is in agreement with the findings of [20].

\section{CONCLUSIONS}

The results obtained during this study found that groundnut seed oil is a good starting material for oil epoxy synthesis. Although there may be competition with food needs because of its edibility, increasing pressure on supply, consolidating on this research would upscale its production and increase its diversification in other areas of application. Under the same reaction conditions of temperature $70^{\circ} \mathrm{C}$, stirring speed of $750 \mathrm{rpm}$, and time of 6 hours, peroxyformic acid was observed to be more efficient for in situ epoxidation than peroxyacetic acid.

However, both carboxylic acids gave good results during the process of epoxidation and acrylation of the oil.

\section{REFERENCES}

[1] Krishan, K. C. 2012. Materials and Engineering. The University of Alabama at Birmingham. USAp, p.133-136

[2] Song, J.H., Murphy, R.J. and Daries, G.B.A. (2009). Bio-degradable and Compositable Alternatives to Conventional Plastics. Royal Society of Biological Sciences. 1526, pp. 2127-2139.

[3] Bakare, F.O. 2015. Development of Biocomposites from Lactic Acid Thermoset Resin and Cellulose Fibre Reinforcements. Swedish Centre for Resource Recovery. University of Boras.

[4] Koronis, G., Silva, A. and Fontul, M. 2013. Green Composites: A Review of Adequate Materials for Automotives Application. Composites Parts B: Engineering. 44, pp.120-127.

[5] Benaniba, M.T., Belhaneche-Bensemra, N. and Gelbard, G. 2008. Epoxidation of Sunflower Oil with Peroxoacetic Acid in Presence of Ion Exchange Resin by Various Processes. Energy Education Science and Technology. 21(2), pp. 71-82.

[6] Saithai, P., Lecomte, J., Dubreucq, E. and Tanrattanakul, V. 2013. Effect of Different Epoxidation Methods of Soybean Oil on The Characteristics of Acrylated Epoxidised Soyabean Oil-Co-Poly(Methyl Methacrylate) Copolymer. Express Polymer Letters. 7(11), pp. 910-924.

[7] Obazee, E.O., Okieimen, F.E., Felix,P.S., Ghosh S., Aigbodion A.I. and Bakare O. I. 2018 Synthesis and Characterization of Acrylated Rubber Seed Oil. J. Chem Soc. Nigeria. 43(3), pp. $499-507$.

[8] Mungroo, R., Pradhan. Goud, V and Dalai, A. 2008. Epoxidation of Canola Oil with hydrogen peroxide catalyzed by Acidic Ion Exchange Resin. Journal of the American Oil Chemists' Society, 85. pp. 887-896.

[9] Okieimen, F.E, Bakare, O.I. and Okieimen, C.O. 2002. Studies on the epoxidation of rubber seed oil. Industrial Crops and Products, 15, pp. 139-144. 
[10] Adekunle, K.F., Akesson, D. and Skrifvars, M. 2010. Synthesis of Reactive Soybean Oils for Use as a Biobased Thermoset Resins in Structural Natural Fiber Composites. Journal of Applied Polymer Science, 115, pp. 3137-3145.

[11] Oresanya, M.O., Akusu, M.O. and David, B.K. 2000. Comparative Studies on the Physiochemical and Sensory Properties of WaterMelon and Seed Flours Used in (Egusi) Soup Preparation. Journal of Food Research. 4(5), pp. 1-5.

[12] Anyasor, G. N., Ogunwenmo, K. O., Oyelana, O. A., Ajayi, D. and Dangana, J. 2009. Chemical Analyses of Groundnut (Arachis hypogaea) oil. Pakistan Journal of Nutrition 8 (3), pp. 269-272.

[13] Wool, R.P. and Sun, X.S. 2005. Bio-Based Polymers and Composites. Elsevier AcademicPress, N.Y.

[14] Ayoola, P.B and Adeyeye, A. 2010. Effect of Heating on The Chemical Composition of Physico-Chemical Properties Arachis Hypogea (Groundnut) Seed Flour Oil and Oil. Pakistan Journal of Nutrition 9(8), pp. 751-754.

[15] Savage, G.P and Keenan, J.I. 1994. The composition and nutritive value of groundnut kernels. In.: smart) (ed). The Groundnut Crop: Scientific basis for improvement London: Chapman and Hall. pp. 173-213.

[16] Staiger, M.P. and Tucker, N. 2008. Natural-Fibre Composites in Structural Applications. In: Pickering K, Properties and Performance of Natural-Fibre Composites. Cambridge, UK: Wood head Publishing, pp.269 -300.

[17] Loh, Y.R., Sujana, D., Rahman, M. and Dasb, C.A. 2013. Sugarcane Bagasse -The future Composite Material: A literature review, Resources, Cons. and Recycling. 75, pp. 14-22

[18] Luz, S.M., Goncalves, A.R. and Del'Arco Jr., A.P. 2007. Mechanical Behavior and Microstructural Analysis of Sugarcane Bagasse Fibers Reinforced Polypropylene Composites. Composites Part A: Applied Science and Manufacturing. 38, pp. $1455-1461$.

[19] Nwosu-Obieogu, K., Aguele, F. O. and Chiemenem, L. I. 2020. Optimization on rubber seed oil epoxidation process parameters using response surface methodology. Iranian journal of chemistry and chemical engineering (IJCCE). Doi:10.30492/ijcce.2020.40345.

[20] Nwosu-Obieogu, K., Hamed, J.O., Anike, E.N., Aguele, F. O., Ukandu, O., Obasi, H.C., Uduma, C.K. and Chiemenem, L. I. 2019. Studies on the epoxidation of groundnut seed oil with carboxylic acid FUTOJNLS. 5, pp. 94-101

\title{
SINTEZA AKRILOVANE EPOKSIDOVANE BIOBAZIRANE SMOLE OD ULJA SEMENA KIKIRIKIJA
}

\author{
Kenechi Nwosu-Obieogu' ${ }^{1}$, Felix Aguele ${ }^{1}$, Linus Chiemenem ${ }^{1}$ \\ ${ }^{1}$ Department of Chemical Engineering, \\ Michael Okpara University of Agriculture, Umidike, Nigeria.
}

Sažetak: U ovoj studiji ulje semena kikirikija je epoksidovano in situ pomoću vodonik-peroksida $(30 \%)$ mravlje i sirćetne kiseline. Uslovi reakcije praćeni su na temperaturi od $70{ }^{\circ} \mathrm{C}$, brzini mešanja od $750 \mathrm{o} / \mathrm{min}$ i vremenu trajanja od 6 sati.

Posle epoksidacije, izvršena je naredna modifikacija upotrebom akrilne kiseline u prisustvu hidrohinona na temperaturi od $120^{\circ} \mathrm{C}$.

U poređenju sa navedenim tretmanima, peroksiformna kiselina se pokazala efikasnijom od peroksiocetne kiseline tokom epoksidacije sa jodnom vrednošću (26,4 gl/ $100 \mathrm{~g}$ ulja) i oxiran sadržajem $(3,27 \%)$. 
FTIR analiza sirovog, epoksidovanog i akrilovanog ulja semenki kikirikija ukazuje na to da semenke kikirkija funkcionalno odgovaraju ovom procesu .

Ključne reči: Ulje semena kikirikija, epoksidacija, akrilacija, mravlja kiselina, sirćetna kiselina.

Prijavljen:

Submitted:

Ispravljen:

Revised:

Prihvaćen:

Accepted:

14.06.2021.

01.09.2021.

01.10.2021. 